УДК 614.2:342.71/.73:61:57:17

DOI https://doi.org/10.32836/2310-9653-2020-3.11

Г. Т. Терешкевич (сестра Діогена), кандидат наук з державного управління, доцент, доцент кафредри українознавства Львівського національного медичного університету імені Данила Галицького, докторант кафедри парламентаризму та політичного менеджменту Національної академії державного управління при Президентові України

\title{
СПЕЦИФІКА БІОЕТИЧНИХ ПИТАНЬ В УКРАЇНСЬКОМУ СУСПІЛЬСТВІ У СФЕРІ ЗАБЕЗПЕЧЕННЯ ПРАВА НА ЖИТТЯ У ВНУТРІШНЬОУТРОБНИЙ ПЕРІОД В КОНТЕКСТІ ДЕРЖАВНОЇ ПОЛІТИКИ В ГАЛУЗІ ОХОРОНИ ЗДОРОВ’Я
}

3 одного боку, демократичний світ веде боротьбу за щсораз нові права людини, з іншого - ті самі права зачатої та ще ненародженої людини, присмертної, соиіально неадаптованої порушує. Моральні аспекти проблеми, які викладає біоетика, надзвичайно важливі, вони допомагають оцінювати проблему переривання вагітності (аборту) з огляду на людську мораль - «благоговіння перед життям».

В Україні все ще відсутнє комплексне наукове дослідження, яке розкрило б сутність засад біоетики у сфері забезпечення права на життя у внутрішньоутробний період у контексті державної політики в галузі охорони здоров'я, що слугуватиме інтересам людини й гармонійному розвитку держави й суспільства.

Метою статті є науково-теоретичне обтрунтування специфіки біоетичних питань у сфері забезпечення права на життя у внутрішньоутробний період у контексті державної політики в галузі охорони здоров'я.

Поширення аборту свідчить про знещінення людського життя. Корінь проблеми лежить у падінні суспільної моралі. Біоетика, яка відстоює гідність і недоторканість людського жстття, засуджує аборт як вбивство невинної людської істоти 6 лоні матері, котре не може бути виправдане ані як мета, ані як засіб досягнення доброї мети. Аборт - ие безповоротна й непоправна смерть дитини у фазі внутрішньоутробного розвитку, насильне втручання в природні проиеси жіночого організму, яке може призводити до психосоматичних і духовних розладів. Обов 'язок лікаря - не нашкодити, завжди стояти на варті життя.

Наслідки аборту відчутні вже тепер: від'ємний показник природного приросту населення, підривання основи сім'ї, фізичні, психологічні, духовні травми в жінок, які вчинили аборт; зростання числа дітей із різними фізичними вадами, створення серйозних проблем у сфері права й законів (закон, який допускає або лібералізує аборт, дискредитує себе, відмовляючись бути рівним для всіх у забезпеченні права на життя) тощо.

Проблеми аборту, а також постабортного синдрому починають розв'язуватися від усвідомлення важскості иъого злочину.

Натепер виникає необхідність переглянути основні нормативно-правові документи щодо проблеми переривання вагітності (аборту), скласти нові з врахуванням положень біоетики й внести відповідні доповнення до основ законодавства.

Ключові слова: біоетика, суспільство, право на життя, аборт, постабортний синдром, система охорони здоров'я, державна політика.

H. T. Tereshkevych (sister Diogena). Specificity of bioethical issues in Ukrainian society in the field of ensuring the right to life in the antenatal period in the context of the state health policy

On the one hand, the democratic world is fighting for new human rights, on the other-violates the same rights of a conceived and unborn person, dying, socially maladapted. The moral aspects of the problem covered by bioethics are extremely important, they help to assess the problem of abortion in terms of human morality - "reverence for life".

There is still no comprehensive scientific study in Ukraine, which revealed the essence of the principles of bioethics in the field of ensuring the right to life in utero in the context of public health policy, which will serve human interests and the harmonious development of the state and society. The purpose of the article is a scientific and theoretical substantiation of the specifics of bioethical issues in the field of ensuring the right to life in utero in the context of public policy in the field of health care.

The spread of abortion indicates the devaluation of human. The root of the problem lies in the decline of public morality. Bioethics, which upholds the dignity and inviolability of human life, condemns abortion as the killing of an innocent human being in the womb, which can be justified neither as a goal nor as a means to an end. Abortion is the irreversible and irreparable death of a child in the phase of fetal development, violent interference in the natural processes of the female body, which can lead to psychosomatic and spiritual disorders. It is the doctor's responsibility not to harm, to always be on guard for life.

The consequences of abortion are already being felt: a negative indicator of natural population growth, the undermining of the family foundation, physical, psychological, spiritual trauma in women who have had an abortion; increasing the number of children with various physical disabilities, creating serious problems in the field of law and laws (a law that allows or liberalizes abortion, discredits itself by refusing to be equal for all in ensuring the right to life), etc.

Problems of abortion, as well as post-abortion syndrome begin to be solved from the realization of the gravity of this crime.

Today there is a need to revise the main legal documents on the problem of abortion (abortion), and to make new ones, taking into account the provisions of bioethics, and to make appropriate additions to the legal framework.

Key words: bioethics, society, right to life, abortion, post-abortion syndrome, health care system, state policy.

(C) Г. Т. Терешкевич (сестра Діогена), 2020 
Постановка проблеми. У системі охорони здоров'я в Україні нагромадилися низка питань біоетичного характеру, розв'язання яких лежить у площині законодавчих змін і відповідно в системі публічного управління. Адже від дій публічних управлінців залежить розвиток країни, життя та здоров’я її громадян.

Натепер ми маємо один із найбільших показників депопуляції населення в Україні. Серед чинників, що впливають на процеси відтворення нації, є репродуктивне здоров'я, яке визначається факторами генетичного характеру, стану довкілля та насамперед статевої культури.

Нині спостерігаємо зіткнення двох протилежних тенденцій: з одного боку - поява нових міжнародних угод і декларацій, які гарантують незаперечне право на життя дитині у фазі внутрішньоутробного розвитку, а також деонтологічних кодексів, що наказують оберігати життя людини від моменту запліднення, а з іншого - поширення законодавства, яке легалізує аборт.

Нині, коли Україна посідає сумні перші місця з приводу легального використання людських ембріонів у лікуванні / фармації / косметології (а в цивілізованому світі фетальна терапія заборонена); коли Україна поповнює жорстоку статистику абортів, у тому числі із «соціальних» причин (щороку у світі вбивають 50-60 млн зачатих і ще ненароджених дітей); коли в Україні народжуються діти з важкими недугами / вадами внаслідок використання неприпустимо шкідливої контрацепції; коли реальну загрозу для життя становить екстракорпоральне запліднення, - ці й інші болючі обставини гостро потребують законодавчих ініціатив, реформ.

Сучасні наукові дослідження у сфері охорони здоров'я сприяють розв'язанню багатьох проблем людини / суспільства. Але всі новітні технології не матимуть правдивої цінності, якщо не враховуватимуть етичні й власне біоетичні засади, в основі яких є повага й збереження життя та здоров’я кожної людської істоти - від моменту запліднення до природної смерті.

Аналіз останніх досліджень і публікацій. Теоретичною основою дослідження стали праці вітчизняних і зарубіжних авторів, присвячені вивченню питань забезпечення права на життя у внутрішньоутробний період у контексті державної політики в галузі охорони здоров’я. В Україні ці питання досліджували: М. Білинська, Ю. Вороненко, В. Гошовська, О. Грищук, Л. Даниленко, В. Загородній, К. Карпенко, В. Кулініченко, Ю. Кундієв, Н. Назар, А. Маркевич, Л. Пашко, С. Пустовіт, М. Чащін, П. Шевчук та інші. Значна увага до зазначених проблем була приділена в роботах зарубіжних вчених: Ж. Ваньє, Н. Вуйчича, Г. Данна, Б. Кловза, Ф. Ней, Дж. Пелуккі, М. Петерс, В. Полтавської, І. Салазар, Ж. Судо, Л. Фрід та інших.

Проте в Україні все ще відсутнє комплексне наукове дослідження, яке розкрило б сутність засад біоетики у сфері забезпечення права на життя у внутрішньоутробний період у контексті державної політики в галузі охорони здоров’я, що слугуватиме інтересам людини й гармонійному розвитку держави й суспільства. У статті вперше в Україні обгрунтовується необхідність внесення засад біоетики в концепцію державотворення та реформування діяльності системи охорони здоров’я відповідно до іїі норм.

Мета статті - науково-теоретичне обгрунтування специфіки біоетичних питань у сфері забезпечення права на життя у внутрішньоутробний період у контексті державної політики в галузі охорони здоров’я, що слугуватиме інтересам людини й гармонійному розвитку держави й суспільства.

Виклад основного матеріалу. Женевська декларація від 1948 р. окреслює обов'язки лікарів у сфері охорони зачатої та ще ненародженої дитини. У ній вміщена Присяга лікаря, яка спирається на загальновідому клятву Гіппократа [1]: «Якнайглибше шануватиму людське життя від моменту його зачаття. Навіть під впливом погроз не буду вживати моїх лікарських знань проти людських прав» [2, с. 33].

Прийняті в Польщі етико-деонтологічні засади зобов'язують лікаря відмовитись від виконання розпоряджень, якщо вони, згідно з його знаннями й сумлінням, шкідливі або неетичні [3, с. 11].

Одна 3 найважливіших причин заперечення дару життя криється в дехристиянізації суспільства. Для багатьох людей Бог перестав існувати, водночас зникла належна пошана до життя та безумовної його гідності. Втративши основу, якою є Бог чи віра, й орієнтуючись на власну систему цінностей, важко визначити, що є добром, а що - злом.

Іншим мотивом боротьби проти життя є концепція абсолютної свободи індивіда, свободи, що стоїть на сторожі лише власних інтересів і потреб згідно зі своїми власними переконаннями. У цій ідеології людське тіло не розглядається як конкретна форма існування, всебічно пов'язана з Богом, а лише зауважується як знаряддя на службі різноманітних пожадань і на службі добробуту. Статевість стає деперсоналізованою, лише засобом чи нагодою отримання задоволення, не розглядається як дар, як вираз справжньої любові, а отже, не відкрита на нове життя.

У світі спостерігається щораз більше проявів драматичної агресивності до людського життя, спрацьовує те, що папа Іван Павло II називає «цивілізацією смерті» [4, с. 58-60]. У сучасному суспільстві спостерігаємо моральне падіння, намагання ігнорувати природне право й пошану людського життя. Аборт стає проблемою моральності не лише індивідуальної, а й суспільної чи навіть політичної.

Мати Тереза з Калькутти зазначила: «Нині найбільший руйнівник світу - це аборт. Якщо мати може вбити свою власну невинну дитину, що ж може тоді утримати людей від вбивства один одного? Тільки Той, Хто створив життя, має право забрати його» [5, с. 108]. 
Аборт поширений нині більше, ніж коли-небудь за всю історію цивілізації. Згідно з даними ВООЗ, у цілому світі щороку здійснюється 50-60 млн абортів (за всю Другу світову війну загинуло 50 млн людей) [5, с. 108]. Згідно з офіційними даними Міністерства охорони здоров'я (далі - МОЗ) України, за 2019 рік у закладах охорони здоров'я було вбито 74 тис. 606 дітей у фазі внутрішньоутробного розвитку, з них 727 - в утробах неповнолітніх осіб [6]. До цієї статистики необхідно долучити новий елемент: перехід до контрацептивних засобів, які, залежно від їх різновидів, часто діють абортивно; суперечать природі як чоловіка, так і жінки, а також їхньому глибокому єднанню; призводять до викиднів; спричинюють вторинну неплідність; шкідливі для життя та здоров’я жінки й потомства [7, с. 127].

Аборт - це перемога гріховної сексуальної революції, яка відбулася за останні роки. Наслідками її стали такі рішення: в 1977 р. в США Конгрес затвердив Акт про контрацепцію, стерилізацію та аборт, маючи «на меті» ввести закон, який начебто мав контролювати нелегальні аборти. Політики, які приймали цей закон, відштовхувалися від того, що тепер аборти будуть проводитися тільки за медичними показаннями. Проте щойно перший аборт став офіційно дозволеним, їх загальна кількість зросла [8, с. 117].

В європейських країнах розрізняють чотири види законів про аборт: найліберальніше законодавство дозволяє «аборт на прохання жінки» (в більшості країн); строгіші закони дозволяють аборт за численними медичними й соціальними показаннями (в Англіі, Угорщині, Ісландії, Люксембурзі, Фінляндії, на Кіпрі); досить строгі закони дозволяють аборт лише за деяких обставин: небезпека фізичного й психічного здоров'я чи життя жінки, вагітність після згвалтування, інцесту, серйозні вади розвитку плода (в Іспанії, Польщі й Швейцарії); закони, які забороняють аборти або дозволяють їх у виключних випадках, коли вагітність становить загрозу життю жінки й дитини (у Північній Ірландії та на Мальті) [9, с. 34-39].

У відсотковому відношенні в 98\% країн аборт дозволений із метою порятунку життя жінки, в $62 \%$ - 3 метою збереження іiі фізичного й психічного здоров'я, в 42\% - у випадку вагітності після насильства, в $40 \%$ - 3 причини дефектів плода, у 29\% - за економічними й соціальними показаннями й у $21 \%$ країн - на прохання жінки [9, с. 34-38].

До країн, в яких законодавство чітко стоїть на позиціях охорони прав зачатої та ще ненародженої дитини, належать країни Південної Америки й басейну Карибського моря, а також європейські держави Андорра, Сан-Марино, Ліхтенштейн, Монако. В Ірландії, на Мальті (як уже було зазначено вище), а також в Об'єднаних Арабських Еміратах, Єгипті, Анголі, Сирії, Смені, Ірані, Афганістані, Шрі-Ланці, на Філіппінах і в інших країнах аборти дозволені лише в разі загрози життю жінки. У 2006 р. в Нікарагуа був прийнятий закон, за яким забороняється аборт, навіть якщо є загроза життю жінки [10, с. 109].

Аборт легкодоступний у найзаселеніших країнах світу: Китаї, Індії, державах колишнього СРСР, США, Канаді, Туреччині, Сгипті, Нігерії, Пакистані, Мексиці, Японії (яка в 1948 р. стала першою країною, що модернізувала своє законодавство стосовно доступності абортів) [10, с. 108].

Аборти були узаконені в більшовицькій Росії (1920р.). Програма абортування, стерилізації та контрацепції входила у фашистську програму знищення слов’янського народу на окупованій території (“eremberg” № 2325). Легалізував аборт колишній Радянський Союз. У 1936 році в СРСР був прийнятий спеціальний декрет про заборону абортів, а вже від 5 серпня 1954 р. Наказом Президії Верховної Ради СРСР кримінальну відповідальність вагітних за здійснення аборту було скасовано. Якщо стаття № 36 «Основ законодавства Російської Федерації про охорону здоров'я населення» дозволяла аборт до 12 тижнів вагітності, а за соціальними показаннями, такими, як смерть чоловіка, багатодітність та інше, - до 22 тижнів [11, с. 12], то вже в 1987 р. межі легальності аборту були розширені за наказом Міністерства охорони здоров’я СРСР № 1342. Цей документ дозволяв «перервати вагітність», тобто аборт, за спеціальними показаннями в пізніші терміни - до 28 тижнів [11, с. 14]. За офіційними даними 1991 р. у колишньому Радянському Союзі проводилися близько 10-13 млн абортів щороку серед 70 млн жінок фертильного віку, з них понад 6 млн абортів були нелегальними [12, с. 108].

Протягом останніх десятиліть законодавство щодо абортів ставало дедалі ліберальнішим. Тепер у різних країнах для легалізації абортів існують свої причини: тяжкі випадки - ризик для здоров'я чи життя матері, кровозмішання, згвалтування чи патологічні відхилення в розвитку плода; погані матеріальні й соціальні умови сім'ї; неефективне вживання контрацептивних засобів; добровільне бажання жінки «перервати вагітність» у першому триместрі й на пізніших етапах вагітності - за медичними й соціальними показаннями [13, с. 178-189]. «Переривання вагітності» ${ }^{1}$ може здійснювати лише кваліфікований лікар і лише в спеціалізованій клініці - такий запис є в законодавствах багатьох країн [14, с. 34-39].

У випадку аборту за медичними показаннями відповідальність несуть лікарі, які повинні визначити, коли вагітність є загрозою для здоров'я та життя жінки. Згідно з визначенням ВООЗ, «здоров'я - це стан повного фізичного, розумового й соціального добробуту, а не тільки відсутність хвороб і фізичних вад», яке є дискутабельним [15, с. 294]. Звідси випливає твердження прихильників абортів: «3 медичного боку необхідним $є$ кожен

${ }^{1}$ Подаємо цей вираз у лапках, бо, на наш погляд, він недосконалий через те, що притемнює справжню природу аборту, зміщує увагу з дитини на жінку та її вагітність і не досить наголошує на вбивстві дитини. 
аборт, про який просить жінка» [15, с. 110]. В Індії аборт дозволений навіть у випадку неефективного вживання контрацептивних засобів, бо це «завдає важкої травми розумовому самопочуттю жінки». Від 1970 р. у деяких країнах Свропи й Азії дозволений аборт за бажанням жінки до 10-12 тижнів вагітності [15, с. 110].

Складна ситуація в нашій державі. Однією з головних причин масового знищення дітей в Україні $є$ чинне законодавство, зокрема ст. 281 («Право на життя») ч. 6 («Штучне переривання вагітності <...>») Цивільного кодексу України від 16 січня 2003 р. (№ 435-IV) [16] і ст. 50 («Добровільне штучне переривання вагітності») Основ законодавства України про охорону здоров’я від 31 грудня 1992 р. (№ 23-92) [17]. Відповідно до цих статей, в Україні дозволені аборти до 12-го тижня вагітності, а від 12-го до 22-го тижня вагітності - «у випадках, встановлених законодавством». Дозвіл законодавства на вчинення абортів оцінює їх як «звичайне хірургічне втручання», створюючи нову ментальність в оцінці людського життя, зокрема зачатого. Твориться нова псевдокультура, яку Папа Іван Павло II назвав «культурою смерті» [18, с. 5-7]. Це суперечить Конституції України, бо відповідно до ст. 3 й ст. 16 Основного Закону «життя, здоров’я та безпека українців є найвищою соціальною цінністю, а збереження генофонду українського народу є обов’язком держави» [19].

Як стверджує українська науковиця Наталя Назар, Цивільний Кодекс України (від 16 січня 2003 р. № 435-IV) у ч. 2 ст. 25 визначає цивільну правоздатність фізичної особи з моменту народження, що вже суперечить засадам біоетики. Таке визначення дитини в законодавстві тягне за собою в ч. 6 ст. 281 цього ж кодексу дозвіл на «штучне переривання вагітності» (аборт) [20]. Згідно із цим Кодексом, правовий статус дитини має особа до досягнення нею повноліття. Малолітньою вважається дитина до досягнення нею чотирнадцяти років (ст. 31 ч. 1). В Кодексі не вказується нижня межа дитинства [21, с. 520].

Відповідно до ст. 115 Кримінального Кодексу України (від 05 квітня 2001 р. № 2341-III), «вагітність незалежно від ії терміну є обтяжувальною обставиною вбивства жінки» [22]. Проте коли йдеться про аборт, правом зачатої дитини на життя нехтують. Тобто маємо прецедент, коли в одному випадку вбивство дитини в лоні матері є обтяжувальною обставиною під час винесення вироку, в іншому ж випадку ми послуговуємося таким самим вбивством, але вже називаючи його «методом планування сім’і», не несучи за цей вчинок жодного покарання чи відповідальності [23, с. 520].

Згідно з даними Держкомстату, нині в Україні ми спостерігаємо складну демографічну ситуацію, коли смертність значно перевищує народжуваність, внаслідок чого ми маємо неухильне зменшення населення України (в середньому на 218 тис. осіб щороку). Величезну роль у цьому відіграють аборти [24, с. 58].

Україна перейняла традиції Радянського Союзу, тому тут сформувалася своєрідна «абортивна культура». Організаційна структура надання медичної допомоги жінкам зорієнтована на здійснення абортів, розробку нових методик цього медичного втручання, підготовку спеціальних медичних кадрів - створення сприятливих умов для здійснення абортів і сприйняття їх як нормального соціального феномену. Велика кількість штучних абортів свідчить, що ті, хто їх чинить, керуються не моральними засадами, а власними інтересами [25, с. 111].

Питання «абортивної ментальності» суспільства в Україні досі належно не розглядається, а статистичні дані кількості «перерваних вагітностей» не розголошуються. За даними ООН, щороку роблять аборти 500-700 тис. жінок України, а народжують лише близько 400 тис. За даними МОЗ України, на 1000 живонароджених припадає 139 абортів. Щороку аборти роблять 400-500 жінок віком 10-14 років, 30-35 тис. підлітків 15-17 років і 600 тис. жінок репродуктивного віку (18-49 років), що часто призводить до подальшого безпліддя. Саме тому різко знижується кількість населення України. Незважаючи на тенденцію до зниження, рівень аборту залишається високим і становить 21,1 на 1000 жінок дітородного віку, або 45,8 на 100 вагітностей. Спостерігається тенденція до збільшення кількості випадків аборту у вперше вагітних, що призводить до високого рівня захворюваності й ризику безплідності в жінок. Прямі репродуктивні втрати від невиношування вагітності щороку становлять 36-40 тис. ненароджених дітей. Головні причини - інфекції, що передаються статевим шляхом, аборт і використання засобів контрацепції. Нині на одну українську родину припадає 0,79 дитини, а кожна п’ята сім'я взагалі не може мати дітей [25, с. 104; 26, с. 111].

Така величезна кількість абортів, яка здійснюється щороку в Україні, свідчить про моральний занепад держави й суспільства. Аборт підриває не лише їх основи, а й передусім основи сім'ї та моральний стан кожної окремої людини. Наслідки аборту несприятливі для всіх: для жінок: велика ймовірність як фізичних, так і психологічних травм чи втрата здатності народжувати дітей у майбутньому; для майбутнього покоління: кількість мертвонароджених дітей і передчасних пологів у жінок, що зробили аборт, збільшується вдвічі; зростає число дітей із різними фізичними вадами; для сім'ї: психічне здоров’я, передусім жінки, надломлюється, моральна єдність подружжя послаблюється, жінка втрачає свою гідність, стає предметом експлуатації з боку чоловіка, сімейна гармонія порушується; для підлітків: невпорядкованість статевого життя, внаслідок чого зростає число одиноких матерів; для держави: виникає демографічна проблема [25, с. 106; 26, с. 111].

Причинами зменшення дітонародження можна вважати не лише соціально-економічні чинники, а й появу в 1970-х роках у США ідеології «чайлдфрі», прибічники якої свідомо відмовляються від народження дітей, незважаючи на таку можливість. 
Нині формується ставлення до абортів як до явища морально нейтрального, що не вважається злочином. Як могло дійти до того, що позбавлення життя втрачає характер «злочину» й отримує статус «закону»; що кожного дня у світі гинуть тисячі ненароджених і беззахисних дітей, йде «війна сильних проти безсилих», виникає своєрідна «змова проти життя»? [26, с. 112; 27, с. 16]. Ми живемо в епоху, коли проблема аборту викликає багато полеміки й різні реакції суспільних груп. Аборт є не лише моральною чи правовою, а й політичною проблемою. Упродовж останніх років у багатьох країнах проводилися кампанії як проти, так і на захист абортів, які подекуди переходили в сутички між прихильниками. Є держави, в яких дискусії щодо абортів завершились легалізацією їх парламентами. Це особливо небезпечно на територіях із малою популяцією певної нації, коли аборти перетворюються на геноцид.

Слово «аборт» походить із латинського “aborior”, що означає «померти до народження». Спробуймо запропонувати стисле й повне визначення аборту, що одночасно було б найправильнішим відбиттям цієї проблеми: «Штучний аборт - це свідоме й безпосереднє (пряме) здійснення вбивства дитини, що перебуває в початковій фазі свого розвитку, тобто між заплідненням і народженням» [26, с. 113].

3 огляду на моральні чинники розрізняємо кілька видів аборту.

Мимовільний аборт (викидень, спонтанний аборт) - незумисна й ніким не спровокована втрата плода всупереч волі матері, яка може через це страждати. За такий аборт жінка не несе моральної відповідальності. Ця дитина залишила слід любові в цьому світі. Тепер вона живе в Господі.

Здебільшого ця проблема розв’язана завдяки розвитку фетології, яка може попередити причини викидня. До них належать анатомічні й гормональні аномалії, інфекційні хвороби під час вагітності, а також хвороби, які передаються статевим шляхом, наприклад сифіліс і такі інші.

Аборт може бути наслідком невідповідної турботи про себе (зокрема на початку вагітності), негативного ставлення чоловіка до жінки під час вагітності, надмірного фізичного навантаження, стресів, незадовільного стану здоров’я жінки, зроблених нею раніше абортів, а також наслідком вживання алкоголю чи наркотиків, паління тощо.

Під час мимовільного аборту відбувається поступове відшарування тканин хоріону (зародкової оболонки) від стінки матки, яке супроводжується пошкодженням іiі кровоносних судин, що приводить до скорочення матки й подальшої кровотечі, внаслідок чого з'являється періодичний біль у нижній частині живота й у попереку. У такому випадку в разі правильного лікування та дотримання суворого ліжкового режиму є шанси зберегти вагітність.

Якщо причиною викидня є очевидний і свідомий вчинок жінки, який безпосередньо провокує мимовільний аборт - це вже моральний злочин (добровільно скоєним абортом є вживання засобів і методів, що перешкоджають імплантації ембріона або зумовлюють викидень) [28, с. 142].

Аборт при ектопічній (позаматковій) вагітності (коли ембріон імплантувався в матковій трубі (в 98\% випадків), чи прикріпився до інших частин тіла: шийки матки, яєчника або стінки черевної порожнини). Така патологія вагітності практично не залишає для дитини жодного шансу, щоб вижити, бо бракує природного середовища, в якому плід міг би розвиватись аж до моменту своєї незалежності. Окрім цього, продовження позаматкової вагітності не тільки призвело б до смерті матері, але не врятувало б життя дитини. Тому в разі імовірності втрати обох людей треба рятувати життя хоча б однієї.

Якщо медицина досягла б таких успіхів, коли можливо пересадити ембріон із фаллопієвої труби в матку, щоб він міг рости, тоді необхідно рятувати й матір, і дитину.

Також є відомі історії, що під час черевної вагітності після операції лапаротомії (розрізу передньої черевної стінки) дитина народилася живою, хоч ризик для мами був великий. Однак медицина розвивається 3 перспективою того, що буде розроблений шанс безпечного ведення такої вагітності з максимальним використанням шансу для дитини, якщо він існує [29, с. 114].

«Терапевтичний» (безпосередній, прямий) аборт. Це ситуація, коли вважають, що жінка перебуває в тяжкому фізичному чи психічному стані, який ускладняється вагітністю. Необхідно зазначити, що йдеться не про терапевтичні заходи для порятунку матері, а про безпосереднє вбивство дитини. Проте жодна людина не має права вирішувати, чиє життя варте порятунку, бо цінність життя та право на життя як для матері, так і для дитини однакові. Здебільшого мати жертвує собою заради дитини. Лікар повинен організувати лікування так, щоб рятувати обох: і матір, і дитину [30, с. 184-185].

Яскравим прикладом жертовності й вірності істині про фундаментальну цінність життя кожної ненародженої дитини є італійський педіатр і хірург Джанна Беретта Молла. Вона жила в епоху зміни морально-суспільних орієнтирів, коли християнські цінності з повсякденного життя витіснялися моральним лібералізмом. Джанна Беретта Молла розуміла, що протистояння християнській моралі призвело б до саморуйнації особистості. Ї̈̈ четверта вагітність проходила з ускладненнями: було виявлено фіброму матки. Дж. Б. Молла відкидає варіанти операцій, які б принесли смерть дитині, обравши варіант із ризиком для власного життя: «Я готова на все, тільки б врятувати моє маля» [31, с. 93]. За тиждень після пологів вона померла. Вона прийняла героїчне рішення зберегти життя своєї ненародженої дитини ціною власного. 2004 року Іван Павло II канонізує Дж. Б. Моллу, попередньо визнавши як покровительку матерів. 
Опосередкований (непрямий) аборт. Якщо вагітна жінка тяжкохвора, наприклад, на рак матки з ураженням ембріона, який не має жодних шансів на виживання, аборт дозволений і морально виправданий, оскільки й матір, і дитина приречені на смерть. Продовження вагітності не тільки призвело б до смерті матері, але й не врятувало б життя дитини. Видаляють хвору матку, а отже й плід. Йдеться про найвищу цінність, якою є людське життя, за умови, що це втручання не можна здійснити після народження дитини, а також неможливо вжити жодного іншого результативного засобу. Такі хірургічні втручання допустимі лише в екстремальних випадках, як-от порятунок життя принаймні матері [32, с. 142].

У такому випадку діє моральний принцип «подвійного наслідку», який полягає в діях, що мають два чи більше наслідків. Цей принцип вимагає виконання таких умов: дія повинна бути морально доброю або індиферентною; намір особи має бути прямим - добрий наслідок має випливати безпосередньо з доброї дії; добрий наслідок має бути в намірі, а поганий - лише таким, якого передбачаємо, але не можемо уникнути; має бути пропорційно вагомий мотив (між добром, яке бажаю досягти, й злом, яке не хочу, але передбачаю) [33, с. 115].

Селективний (євгенічний) аборт виконують, щоб запобігти народженню дитини з генетичними відхиленнями. Згідно із цією ідеологією, лише сильні особистості, здорові, корисні для суспільства мають право на життя. Такий прагматизм дуже небезпечний (прикладом цього є події Другої світової війни), бо призводить до расизму й евтаназії. Щодо етичного аспекту цього питання, то немає жодних сумнівів, що він неморальний і неприпустимий. Не можна наголошувати на якості життя, не беручи до уваги водночас цінність життя та право на нього. Не існує жодних причин, навіть аномалій плода, які б усправедливлювали позбавлення людського плода його індивідуальності й гідності. Євгенічні аборти чиняться батьками з егоїстичних причин, щоб позбавити себе страждань і клопотів, пов’язаних із доглядом за неповносправними. 3 погляду біоетики наявність будь-якої неповносправності ніяк не впливає на онтологічну сутність дитини, яка не повинна вилучатися із суспільства, а навпаки - потребує від нього допомоги й захисту. Усі рівні в очах Бога мають однакову гідність незалежно від їхнього фізичного розвитку. Оскільки кожна людина носить у собі «образ Бога», аборт $\epsilon$ замахом на самого Бога, а відмова від дитини з особливими проблемами здоров'я є відкиненням Божого дару [33, с. 115].

Добрим прикладом є заснована Ж. Ваньє спільнота «Ковчег», яка має на меті показати шлях, прокладений Ісусом для всіх, що бажають іти за Ним. Ця дорога є джерелом одужання, бо веде нас зі знедоленими, слабкими й пригнобленими через єднання з ними в любові до Христа й Отця Його, дає змогу відчути разом із людьми, що мають різні вади, пасхальні таємниці Христа - вмерти для Воскресіння [34, с. 5-10].

Ісус присутній у цих нещасних розбитих тілах. Їхні рани - то Його рани. Розбиті тіла спроможні стати життєдайним джерелом, бо з пораненого боку розп’ятого Христа пролилися кров і вода, котрі врятували світ.

3 огляду на онтологічну сутність людини, іiі життю притаманна гідність, недоторканість і найвища цінність на всіх етапах існування, у всіх його станах, у нормі й патології.

Нік Вуйчич - всесвітньо відомий мотиватор для людей з особливими проблемами здоров'я на власному прикладі переконливо доводить, що для того, щоб жити повноцінним життям, досягати успіху в кар'єрі й особистому житті, не обов'язково бути схожим на інших. Він народився без рук і ніг, зміг не просто реалізувати себе, але надихнути своїм прикладом тисячі інших людей [35, с. 1-354].

Аборт як наслідок згвалтування. Не можна у випадку вагітності через згвалтування чи інцесту шукати рекомпенсації справедливості, застосовуючи як засіб ще більшу несправедливість, якою є переривання життя вже зачатої дитини. Відомі багато свідчень людей, які були зачаті внаслідок згвалтування в роки II світової війни й завдячують своїм матерям за своє народження.

Вагітність внаслідок згвалтування чи інцесту трапляється нечасто (1\% у США) [36, с. 188]. Діти, зачаті внаслідок згвалтування чи інцесту, залишаються людськими особами. Вони мають право на життя, як і ті діти, які були зачаті в подружній любові, й тому також заслуговують на захист. Усі діти, незалежно від того, чи вони народилися 3 подружнього чи з позашлюбного зв'язку, мають рівні права щодо суспільної опіки й піклування про розвиток їх особистості [37, с. 96-102]. Аборт не може бути розв'язанням проблеми згвалтування. Покарання гвалтівника (в значенні ресоціалізації) та турбота про жертву, щоб вона відчула фізичне й емоційне зцілення, є єдиним правильним рішенням у цій ситуації [37, с. 153-168].

Суспільний (соиіальний) аборт. Іноді до аборту вдаються з різноманітних суспільних мотивів: економічні труднощі сім’ї; страх жінки перед втратою праці, дотеперішнього стилю життя, вільного часу; страх перед відповідальністю; незрілість, зокрема молодих людей, що не готові прийняти дитину й таке інше. Споживацький спосіб життя як у країнах високорозвинених, так і в тих, що розвиваються, спричинює зниження природного приросту населення. Не дивно, що в Свропі з'являється щораз більше країн з від'ємним показником природного приросту населення. В Україні, як вже було зазначено, рівень народжуваності не забезпечує простого відтворення населення - показник народжуваності менший від рівня загальної смертності.

3 позицій персоналістичної біоетики жодні аргументи, ні економічні, ні психологічні, ні інтереси суспільства не можуть вести до знищення життя невинних створінь, бо ціна людського життя найвища. 
У Львові є пам'ятник «...І живим, і мертвим, і ненародженим... абортованим дітям», який зініціював о. Мирослав Солтис на території дитячого садочка. Скульптор пам'ятника - Орест Драган. Підніжжя пам’ятника дзвін, потрісканий від дитячого крику й плачу. Між каміннями вимуровано в різних місцях підніжжя ембріон, ручку, ніжку, голівку дитини. Над підніжжям ангели підіймають на хмарах Богородицю, яка простягає руки до ненародженого немовлятка. До нього, як до священника, приходили за порадою люди, які хотіли вчинити аборт iз певних мотивів. Відповідь священника завжди категорична: «Не вбий! Ти - людина. Ти - християнка!» Деякі матері народжують i, на жаль, залишають дітей у цьому садочку, який стає для них притулком [38, с. 116].

Нині в багатьох країнах розвинута мережа «бебі-боксів» («Вікна життя») - це спеціально облаштовані скриньки для новонароджених дітей, яких анонімно покидають матері. «Бебі-бокси» розміщені поблизу лікарень, працівники яких несуть пряму відповідальність за життя дитини. Жінці дається короткий час для переосмислення вчинку й можливості забрати малюка. Добре, що нині $є$ багато охочих прийняти у свою сім'ю покинутих дітей [38, с. 116-117].

Експеримент, проведений у нью-йоркській клініці Бернарда Натансона (відповідального за здійснення 75000 абортів, який потім навернувся, автора всесвітньо відомих фільмів «Німий крик» і «Втрата розуму», показав, що 9 із 10 жінок, які вирішили зробити аборт, відмовляються від цього наміру, побачивши свою дитину на моніторі ультразвукової діагностики [39, с. 1-22].

Проблема абортів постає для суспільства й кожної окремої сім’ї багатьма негативними моральними, правовими, суспільними й політичними аспектами. Релігія, яка відстоює святість людського життя, засуджує аборт як убивство ненародженої дитини. Моральні аспекти проблеми, які викладає біоетика, надзвичайно важливі, вони допомагають оцінювати проблему аборту через призму людської моралі - благоговіння перед життям.

Бог є Автором і Володарем життя та має план на кожну людину.

У документах II Ватиканського Собору зазначено: «Бог, Господь життя, дав людям це прегарне служіння, яке слід виповняти способом, достойним людини. Тому вже від самого зачаття треба з найбільшою пильністю берегти життя, скидання плоду й дітовбивство є мерзенним злочином» [40, с. 51].

На жаль, нині часто функція лікаря-гінеколога розцінюється як вмілого високооплачуваного спеціаліста з розв’язання проблеми «небажаної» вагітності. І причина проблеми лежить у бажанні не прийняти нове людське життя як дарунок Божий часто через втрату комфорту.

Наші батьки колись теж дозволили нам народитися. А якби вони нас убили? Яким був би світ без нас?? Прикладом є американський винахідник і підприємець Стів Джобс (якого біологічна мати - 17-річна студентка - після народження віддала у приймальну сім’ю)!

Нині назріла необхідність переглянути основні нормативно-правові документи щодо проблеми аборту, скласти нові, взявши до уваги засади персоналістичної біоетики, й внести відповідні корективи до основ законодавства.

Всесвітньо відома п’єса за мотивами роману сучасного французького драматурга Е.Е. Шмітта «Оскар і Рожева пані», яка неодноразово ставилася провідними акторами й режисерами в різних країнах світу, розповідає про історію маленького хлопчика, якому залишилось жити декілька днів. За цей час він встигає написати 14 послань до Бога, в яких описує свої переживання, водночас ніби складає майбутнє, якого не матиме. Задум драматурга полягав у тому, щоб спонукати глядача цінувати кожну мить у житті [41, с. 117].

Наведемо один із діалогів лікаря з жінкою, завдяки якому вона, ідучи на аборт, змінила своє рішення.

До одного чесного лікаря приходить молода вагітна жінка, щоб позбутися ненародженої дитини. А він каже до неї: «Пані, але це може зашкодити вашому здоров'ю. Ми можемо зробити по-іншому. Дозвольте, нехай дитина прийде на світ. А тоді її заріжете». Жінка, почувши про такий план, образилася: «Що ви таке говорите? Де ж би я вбила свою дитину?!». А тоді лікар відповідає: «Але ж, пані, яке це має значення? Дитина після народження лише на декілька місяців старша. Коли злочином є вбити іiі одразу після народження, то такий самий злочин убити ії живою у вашому лоні» [41, с. 117]. Такий сміливий діалог майбутніх і теперішніх лікарів-гінекологів зміг би переконати не одну матір зберегти життя своєї дитини.

Людина не повинна підкорятися морально неприпустимим за своєю суттю законам. Протест сумління медичних працівників засвідчує вірність фахові, є важливим засобом суспільного виявлення несправедливості закону, який дозволяє дії, спрямовані проти невинного безборонного людського життя, яке має фундаментальну цінність $[42$, с. $143 ; 43]$.

Вагітна жінка має відвідувати лікаря-гінеколога 3 метою контролю стану власного здоров'я та здоров'я плода, а також для виявлення в ембріона відхилень у розвитку чи будь-яких інших дефектів, що можуть вплинути на його майбутнє життя [44, с. 118].

Пренатальна діагностика - це діагностика перед пологами з метою виявлення можливих вад розвитку або дефектів у дитини, що розвивається, а також стану перебігу вагітності.

Методи пренатальної діагностики класифікують у залежності від різновиду діагностичної інформації (морфофункціональна, цитогенетична, біохіміко-метаболічна, клініко-мікробіологічна) й інвазивності діагностичної процедури (неінвазивні, інвазивні). 
Неінвазивні методи:

- ультразвукове дослідження (далі - УЗД) плода. Проводять для контролю за ростом і розміщенням плода, а також за розвитком частин його тіла й внутрішніх органів;

- магнітно-ядерний резонанс. $Є$ новітнім та інформативнішим методом діагностики. Дозволяє отримувати детальне зображення плода із середини матки;

- генетичне консультування та імунологічні дослідження. Печінка плода продукує білок - альфа-протеїн, що потрапляє в кров матері, де його й виміряють. Підвищення концентрації цього білка може свідчити про ймовірність багатоплідної вагітності або вад розвитку плода;

- потрійний тест (потрійний тест Барта). С тестом на ймовірність хромосомної патології (зокрема, синдрому Дауна). Досліджує три елементи в крові матері: білок - альфа-протеїн (АФП), гормони - естріол (НЕ), людський хоріонічний гонадотропін (лХГ). За показниками вмісту цих трьох біохімічних маркерів, а також віку матері визначають ймовірність ураження плода синдромом Дауна.

У разі необхідності досліджують аналіз клітинного матеріалу, який отримують за допомогою складніших інвазійних процедур, котрі, однак, можуть спричинити викидень:

- амніоцентез - дослідження навколоплідної рідини й клітин плода (за допомогою голки, під контролем УЗД) із метою вивчення хромосом (ризик викидня - 1/100);

- дослідження ворсинок хоріона, або біопсія (за допомогою фетоскопії та під контролем УЗД). Беруть невеличкі частинки хоріону (поза ембріональної тканини, яка живить ембріон), щоб згодом піддати його генетичному й мікробіологічному дослідженню (ймовірність викидня 8-10\% або ушкодження пальців чи рук плода);

- кордоцентез - взяття пуповинної крові (під контролем УЗД проколюють вену пуповини й отримують кров плода та ії аналізують). Метод допомагає в діагностуванні імунодефіцитів і хвороб крові (наприклад, гемофілії) (ризик викидня складає $0,5-1,5 \%$ або ускладнення: зародкова брадикардія, тимчасова тахікардія та кровотеча 3 пуповини);

- ембріоскопія чи фетоскопія полягають у введенні мініатюрного ембріоскопа або більшого розмірами фетоскопа з оптичних волокон у порожнину матки з метою роздивитись стан ембріону або для доставлення туди необхідних ліків (у разі застосування ембріоскопії ризик викидня 2-3\%, а фетоскопії - 4-6\%, ранні пологи - 8\%);

- плацентоцентез полягає в отриманні крові плода через проколювання плаценти для наступного ії аналізу (ризик викидня - 7-10\%).

Пренатальна діагностика дає змогу довідатись про стан ембріона в материнському лоні, що забезпечує своєчасність і підвищує ефективність лікування дитини. Така діагностика за згодою батьків дитини дозволена після повної поінформованості останніх про те, що застосовані методи збережуть життя та цілісність ембріона й матері, не наражаючи їх на невиправданий (непропорційно високий) ризик. Однак діагностика, заради отримання результатів для вчинення аборту суперечить моральному закону. Диференційна діагностика, яка виявляє дефекти розвитку плода чи спадкову хворобу, не повинна бути смертним вироком [45, с. 1-2]!

«Належить звернути особливу увагу на моральну оцінку передпологових діагностичних технологій, що дозволяють виявити можливі аномалії в організмі ще не народженої дитини. Саме з огляду на складність тих технік їхня оцінка має бути якнайдокладнішою та виваженою. Вони морально виправдані, якщо не становлять надмірної загрози для дитини й матері та якщо застосовуються, щоб здійснити вчасне лікування чи допомогти спокійно й свідомо прийняти дитину, що має народитись. Однак <...> часто буває, що ці технології прислуговуються євгенічній ментальності, <..> аби запобігти народженню дітей, уражених якимись аномаліями. Такий спосіб мислення є ганебним і гідним всілякого осуду <... $>[46$, с. 63$]$.

Залежно від терміну вагітності аборти поділяються на ранні аборти (до 12 тижня вагітності) й пізні (від 12 до 22 тижні вагітності).

Аборт може бути вчинений різноманітними хірургічними чи фармакологічними методами [47, с. 118-120]. До хірургічних методів належать:

- від 3 до 4 тижні життя дитини використовують вакуум-аспірацію (мініаборт) - тіло дитини під дією тиску вакуумного відсмоктувача розривається на шматки, втягується в трубку й викидається в резервуар;

- у терміні вагітності 12 тижнів проводять розширення та вишкрябування (інструментальний метод) - спеціальними інструментами розкривають шийку матки, через яку гострою кюреткою відривають ембріон від ії стінки, шматуючи його тіло й вишкрібаючи матку до повного видалення всіх тканин ембріона, плаценти й функціонального шару ендометрію;

- від 16 до 22 тижні вагітності застосовують інтраамніотичне введення гіпертонічних розчинів (внутрішньоматкова ін'єкція) - введення певної кількості гіпертонічного розчину хлориду натрію або іншої отруйної речовини, попередньо відсмоктавши таку ж кількість навколоплідних вод, що призводить до тяжких мук із подальшим удушенням і смертю дитини.

До фармакологічних методів (медикаментозний аборт) належать:

$R U-486$ (міфепристон) - антипрогестиновий препарат, що блокує прогестеронові рецептори матки. Він застосовується до 50-го дня вагітності. Дія прогестерону забезпечує нормальний розвиток вагітності, а блокування дії цього 
гормону провокує ранній аборт, спричинюючи скорочення матки. У разі неповного відшарування плаценти вона може залишатися в порожнині матки, що супроводжується небезпечною кровотечею та необхідністю хірургічного втручання. RU-486 може спричинити токсичне ураження печінки й гостру серцеву недостатність. У багатьох країнах він заборонений.

Простагландини - фармакологічні препарати, які використовують із метою стимуляції родової діяльності, що призводить до викидня. Вони впливають на скорочення та розслаблення гладких м'язів, на функцію ендокринних, а отже й статевих залоз, на центральну нервову систему, кровообіг, дихання тощо. На 5-27-му тижні вагітності застосовують різні шляхи введення в організм матері простагландинів - через рот, внутрішньовенно, підшкірно, внутрішньом'язово, а також безпосередньо в амніотичну рідину.

Абортивна вакцина (anti-human Chorionik Gonadotropin, anti-Trofoblastic Antigen) - протидіє внутрішньоутробному розвитку дитини, бо після її введення в організмі матері утворюються антитіла до гормонів, якими зародок сигналізує матір про своє існування після імплантації.

Внутрішньоматкові засоби (спіралі). Це вироби різної форми, які вставляють у порожнину матки. Їх часто представляють як «контрацептивний» засіб. Механізм дії спіралі:

- травматичне ушкодження та, як наслідок, запалення ендометрію матки, що перешкоджає імплантації та розвитку ембріона;

- стимулювання сильних скорочень матки, яка виштовхує ембріон (через що сильні болі на початку так званих місячних, тоді коли насправді відбувається відштовхування та вигнання дитини з тіла матері);

- десинхронізовані скорочення матки й маткових труб (гальмування перистальтики маткових труб, внаслідок чого затримується пересування до матки зачатої дитини, що може призвести до позаматкової вагітності).

Спіралі, які містять гормони або інші хімічні речовини, мають низку додаткових ефектів. Спіралі 3 вмістом прогестероноподібних речовин гальмують розвиток ендометрію. Внутрішньоматкові засоби, що містять іони міді, впливають на дозрівання сперматозоїдів, а спіралі, які містять іони срібла, посилюють перистальтику маткових труб. Застосування спіралей у 9\% випадків неефективне.

Таблетка «наступного дня» пригнічує функцію жовтого тіла й викликає зміни в слизовій оболонці матки, що перешкоджає імплантації зародка. Проте, якщо не відбулася імплантація, то відбувається ранній штучний аборт (застосовується до 72 годин після статевого співжиття).

У разі застосування трьох останніх фармакологічних методів аборт залишається непоміченим жінкою, оскільки він здійснюється на ранніх етапах розвитку дитини (ще до імплантації).

Є й інші небезпечні методи й способи провокування аборту. Жінки можуть свідомо й прямо провокувати викидні на ранніх етапах розвитку дитини за допомогою різних засобів і способів. Внаслідок цих дій виникають маткові кровотечі, хімічні опіки, гнійне запалення внутрішніх статевих органів, сепсис тощо. Іноді заради врятування життя жінки видаляють матку.

Окрім цього, будь-який із видів аборту є не тільки загрозливим для життя та здоров'я жінки, а й призводить до викиднів у разі наступної вагітності й неплідності жінки.

Штучний аборт - це завжди смерть дитини й втручання в природні процеси жіночого організму, які можуть призводити до психосоматичних або навіть духовних розладів.

Заборона абортів привела б до покращення репродуктивного здоров'я жінок, росту народжуваності й, таким чином, до припинення негативних тенденцій депопуляції.

Батьки, а особливо мати, завжди несуть пряму відповідальність за життя своєї дитини. Часто жінки, які перенесли аборт, страждають від глибокого почуття провини через причетність до загибелі плода. Постабортний синдром (далі-ПАС) - це поєднання психічних симптомів і захворювань, які виникають внаслідок переживань із приводу вчиненого аборту [47, с. 120].

Більшість жінок тривалий час після аборту відчувають вину й страх, у них виникають тяжкі депресії, а також фізичні недуги: мігрень, аритмії серця, шлунково-кишкові захворювання. Часто виникають проблеми у взаєминах із партнером: почуття ненависті й статевої байдужості. Замість очікуваного звільнення від проблем з'являються нові: руйнуються стосунки з рідними, батьком дитини. Для жінки найбільшою проблемою після аборту є відновлення внутрішнього спокою. Вона намагається уникати спогадів про дитину, виникають конфлікти 3 чоловіком, коли аборт вчинений без його відома й таке інше.

Американські терапевти подають такий перелік наслідків аборту для жінки: шок, аналогічний шоку після нещасного випадку; розлади сну, жахливі сновидіння; неадекватна реакція на вагітних жінок і малих дітей, зокрема панічний страх перед ними; бажання все забути; намагання «виправити» аборт повторною вагітністю; слабка зосередженість, пасивність або навпаки, надактивність; неадекватні емоційні реакції на шуми, вигляд немовля; погіршене емоційне світосприйняття; постійні згадки про аборт; агресивність щодо батька дитини, лікаря, до усіх чоловіків і самої себе; спроби самовиправдання через відмовляння чи намовляння інших до аборту; статева байдужість; депресія; почуття вини; само агресія; зловживання медикаментами, алкоголем, наркотиками [47, с. 120]. 
Постабортний синдром дуже негативно змінює психологію, світогляд і все подальше життя не лише жінки, що перенесла аборт, а й усіх причетних до нього. ПАС негативно впливає на подружжя: після аборту розпадається кожна четверта пара (не може чоловік любити жінку, яка вбила його дитину), а жінка не може поважати чоловіка, який дозволив їй це зробити. «Постабортний батько», якого Бог створив бути захисником, годувальником, батьком, незалежно від того, чи усвідомлює він це чи ні, підсвідомо відчуває сором, сум, депресію, гнів, страх [48, c. 59].

Жінка, яка вчинила аборт, може неадекватно поводитися зі своїми дітьми й реагувати на їхні потреби. У дітей, що виростають у сім'ях, де був зроблений аборт, спостерігається загострене відчуття страху, нездатність радіти життю, схильність до агресивної поведінки стосовно батьків, авторитетів і самих себе, що може проявлятися у формі суїцидальних схильностей, а також нездатності створення міцної сім’ї [48, с. 60].

Лікар, який чинить аборт або причетний до нього, переживає постабортний синдром підсвідомо. Симптоми ПАСу можуть 3'явитися навіть після того, як людина давно забула про причетність до аборту. Моральний обов'язок лікарів - повідомити жінці правду про аборт, пояснити, що в лоні матері від моменту запліднення перебуває не «згусток клітин», а розвивається живий організм з усіма ознаками індивідуальності людської особи, й що аборт - це вбивство дитини, а також попередити вагітну жінку про всі можливі наслідки аборту - постабортний синдром.

Проблема постабортного синдрому дуже складна, й для допомоги жінці потрібний адекватний підхід 3 урахуванням особливостей конкретної ситуації. Для лікування тілесних недуг потерпілим від аборту та його наслідків - ПАСу необхідні реабілітаційні центри, забезпечені кваліфікованими лікарями й психологами з відповідною фаховою підготовкою. Проте фізичні й психічні проблеми в жінок після проведеного аборту, які базуються на пошкодженні цілісності жіночого організму (духовної, душевної та тілесної єдності), неможливо розв’язати лише тілесним лікуванням і психічним відновленням. Адже коренем хвороби є порушення Божої заповіді «Не вбий». Тому найпершим та основним лікуванням післяабортних проблем є духовне зцілення людини через Покаяння [49, с. 99-104].

Необхідно визнати й оплакати втрату дитини, просити в Господа й дитини прощення, в Ньому простити собі й всім, хто причетний до її втрати, дати дитині ім’я, благословити іï, віддати дитину в руки Господа. Вона тепер живе в Бозі.

Часто жінки кажуть, що після аборту все подальше життя їх мучить совість (сумління). Саме совість людини той природний моральний закон, який написаний Творцем у серці кожної людини.

Совість (сумління) - це вияв моральної самосвідомості особистості, їі здатність здійснювати моральний самоконтроль, самостійно формулювати для себе моральні обов'язки, вимагати від себе їхнього виконання та здійснювати оцінку своїх вчинків [50, с. 341]. Сумління як природний закон, притаманний усім людям, є критерієм моральності [50, с. 6]. Совість - це внутрішнє духовне осмислення людиною цілісності своєї життєвої реалізації під кутом зору їі принципової моральної оцінки. Совість, що означає моральну обізнаність або свідомість, реагує, коли дії людини, думки й слова відповідають або суперечать іiї стандартам щодо того, що є правильно й неправильно. Совість є даною Богом здатністю людини до самооцінки. Апостол Павло кілька разів називає свою власну совість «невинною» (Дії 23, 1; 24, 16), (1 Кор. 4, 4) [51]. Він аналізує свої слова й вчинки й виявляє, що вони відповідають його системі моралі й цінностей, які, звичайно ж, грунтуються на Божих стандартах. Його совість підтверджує чистоту його серця. Апостол Павло говорить, що язичники мають совість, що свідчить про те, що Закон Божий записаний в їхніх серцях, навіть якщо вони й не знали закону Мойсея (Рим. 2, 14-15) [51]. Він також називає свою совість свідком того, що він говорить правду (Рим. 9, 1) і поводиться $з$ оточенням у святості й щирості $(2$ Кор. 1, 12) [51]. Окрім цього, він каже, що його совість говорить, що його дії не залишаються непоміченими для Бога, й сподівається, що й в інших людей совість виконує таку ж функцію $(2$ Кор. 5,11$)$ [51]. Совість слугує системі цінностей людини. Слабка система цінностей веде до немічної совісті, тоді як зріла система цінностей веде до сильного відчуття того, що є правильним, а що - ні. Становлення у вірі зміцнює совість. Якщо наша совість є чистою завдяки зрілій вірі, то ми не маємо стати причиною того, що ті, в кого вона слабша, похитнуться від наших дій, а зважаємо на них, ставлячись із християнською любов'ю та співчуттям (як, наприклад, апостол Павло закликав тих, хто був зрілішим у вірі, не застосовувати свою свободу щодо вживання їжі (хоча це не має жодного значення, чи була їжа принесена в жертву ідолам, які не є реальними богами, чи ні), якщо це могло б призвести до того, що совість їхніх менш зрілих братів засуджувала б ці дії, грунтуючись на забобонах і марновірних переконаннях). Бувши християнином, людська особа має зберігати свою совість у чистоті, підкоряючись Богові й підтримуючи з Ним належні стосунки, застосовуючи Його Слово, яке постійно оновлює й пом'якшує людські серця. Людина зі спаленою та нечутливою совістю більше не чує тї спонукань і може грішити ще більше, обманювати себе, думаючи, що з ії душею все добре, й ставитися до інших із байдужістю та без співчуття (1 Тим. 4,1-2) [51].

Лікарі-психологи засвідчують, що всіх жінок, які звертались до них по допомогу, незалежно від їхньої культури, хвилює питання про духовну природу людини та її взаємини з Богом. Це природний поклик серця людини 
до Бога, до Покаяння, яке може очистити совість і з Божою допомогою повернути жінці самоповагу, почуття власної гідності й власної неповторності, щоб продовжувати своє життя в радості й любові. Папа Іван Павло II в енцикліці “Evangelium Vitae” («Євангеліє життя») звертається до жінок, які вчинили аборт: «3 покірністю та довірою покайтеся, якщо досі ще цього не зробили. Отець усього милосердя чекає на вас, щоб подарувати вам Своє прощення та мир у Таїнстві Примирення. Ви зможете попросити пробачення у своєї дитини: вона тепер живе в Бозі. Спираючись на допомогу й пораду ваших прихильників і досвідчених людей, ви зможете зробити свій болісний досвід чи не найпереконливішим аргументом в обороні вселюдського права на життя. Ваша самовідданість у служінні життю, яка може увінчатися народженням нових людських істот, ваша готовність до прийняття та турботи про тих, хто найбільше потребує вашої близькості, спонукає по-новому побачити людське життя» [52, с. 99].

У Словаччині споруджено Пам'ятник ненародженим дітям. У меморіальній композиції жінка знаходиться обличчям до церкви, що символізує її розкаяння. Людина, яка вважала себе богом, що може розпоряджатися життям інших, повернулася обличчям до справжнього Бога. Фігура ненародженої дитини з напівпрозорого матеріалу виражає жест прощення [53, с. 122].

15 жовтня відзначається Всесвітній день дітей, які відійшли від нас під час вагітності чи після народження, залишивши слід любові в цьому світі. Це важлива нагода, щоб розірвати мовчанку, згадати дітей, відзначити їхні короткі життя, проголосити їхні імена, поділитися їхніми історіями й дивитися понад біль втрати з надією в майбутнє.

На сучасному етапі процес становлення демократичного суспільства реалізується через захист прав і свобод людини. А хіба це можливо, якщо здійснюються такі жорстокі вбивства ще в утробі матері й без захисту залишаються найсвятіші - матір і дитина? Завданням держави є турбота про кожне людське життя: в школах необхідно виховувати відповідальність і пошану життя; в політичному житті поборювати несправедливі «про абортні» закони й створювати нові, які цілковито визнають гідність людини; вимагати заборони всіх світських законів, що руйнують материнство й дитинство; підтримувати й допомагати всім тим, хто виступає проти несправедливого права; популяризувати знання про ПАС, особливо через ЗМІ, серед широкої громадськості. Необхідне таке законодавство, яке б не суперечило цінностям життя на будь-якому етапі його існування. Кожний громадянин - виборець, певною мірою відповідальний за законодавство своєї держави, тому треба ретельно аналізувати, за яке законодавство він голосує. Людина не має підкорятися законам, які по суті етично неприпустимі, зокрема законові, який дозволяє аборт.

Висновки $з$ дослідження і перспективи подальших розвідок у цьому напрямі. Велика кількість абортів, які щорічно здійснюються в державі, призводить до погіршення стану здоров'я найбільш працездатної частини жіноцтва, падіння народжуваності й росту смертності, зростання кількості безплідних подружніх пар, що становить загрозу національній безпеці України. Органам державної влади й місцевого самоврядування, громадським організаціям необхідно вжити всіх можливих заходів щодо витіснення абортів із життя суспільства.

Державною програмою, яка суттєво збільшить рівень народжуваності дітей, має стати профілактика абортів, контрацепції, розв'язання проблеми руйнівного постабортного синдрому, вивчення природних методів розпізнавання днів плідності, формування нової демографічної культури, посилення сімейно-шлюбних відносин.

Верховній Раді України: необхідно внести корективи в нормативно-правові акти, які стосуються сфери охорони здоров'я, узгодивши їх із засадами біоетики, забезпечивши право людини на життя від моменту запліднення; слід активізувати законотворчу роботу в царині охорони материнства й дитинства; залучати до діяльності робочі групи, які займаються підготовкою нормативно-правових актів у сфері охорони здоров'я, фахівців із персоналістичної біоетики, організаторів охорони здоров'я, медичних і фармацевтичних працівників та інших спеціалістів, які стоять на засадах біоетики; варто забезпечувати проведення громадських слухань із найактуальніших і дискусійних проблем біоетики виробленням фахових рекомендацій; потрібно прийняти Закон про заборону абортів в Україні (без залучення великих бюджетних коштів); для проведення необхідних робіт щодо обгрунтування необхідності закону, прогнозування можливих наслідків заборони абортів, їхньому статистичному дослідженню, а також для розробки законодавчої бази створити ініціативну групу із залученням до роботи працівників зацікавлених освітніх і наукових закладів, органів державної влади й місцевого самоврядування, які стоять на позиції біоетики.

Кабінету Міністрів України, Міністерству охорони здоров’я України в час демографічної кризи 3 метою збільшення народжуваності законодавчо заборонити проведення абортів, забезпечити безкоштовне обстеження дітей, молоді, вагітних жінок у всіх державних медичних закладах.

Міністерству охорони здоров'я необхідно розгорнути в Україні широку інформаційно-просвітницьку компанію щодо заохочення народжуваності й запобігання абортів; ініціювати співпрацю з мережами аптек, щоб під час покупки тестів на вагітність вручати покупцю інформаційний бюлетень про цінність людського життя від моменту запліднення; розширити центри планування сім’ї з вивчення природних методів розпізнавання плідності на практиці акушерсько-гінекологічної служби; підвищувати кваліфікацію фахівців, які причетні до інформаційно-консультативної діяльності щодо цих питань; формувати суспільну спрямованість здорового способу життя, передусім щодо питань, які стосуються репродуктивного здоров’я людини. 
Міністерству освіти й науки України варто провести аналіз наявних навчальних програм шкіл і закладів вищої освіти щодо питань статевого виховання, наголошуючи на непорушності цінності людського життя; пропагувати зміцнення сім’ї, подружню вірність і дошлюбну стриманість, надавати об'єктивну інформацію про сутність аборту та його негативні наслідки. До розробки нових програм і матеріалів залучати громадські й релігійні організації; провести аналіз концептуальних положень освітніх і медичних програм, що базуються на ідеях планування сім’ї.

Органам державної влади й органам місцевого самоврядування варто сприяти в реалізації державної політики у сфері охорони здоров'я на засадах біоетики; потрібно залучати духовенство до пропаганди здорового способу життя.

Поліклінічним закладам доцільно посилити систему консультування вагітних жінок (і подружніх пар), які мають намір зробити аборт, із метою сприяння збереженню кожної вагітності; створити кабінети виношування вагітності; до цієї роботи, окрім медичних працівників, залучати психологів, представників громадських та релігійних організацій у межах чинного законодавства 3 дотриманням конфіденційності інформації та лікарської таємниці.

Працівникам акушерсько-гінекологічного напрямку медицини слід проводити активну агітацію за навчання природного методу розпізнавання днів плідності жінки; інформувати про небезпечні наслідки застосування контрацептивних засобів та ймовірності настання абортивного ефекту під час їх застосування.

Лікарям, медсестрам, акушеркам, фармацевтам слід надавати жінкам правдиву інформацію про шкоду, негативний вплив аборту на організм, психіку жінки; шкідливу дію засобів контрацепції (зокрема абортивну дію спіралей, гормональних препаратів), а також про постабортний синдром.

Засобам масової інформації доцільно створити всеосяжну систему інформаційного забезпечення суспільства про шкідливість аборту; збільшити рівень інформованості громадян України про природні методи розпізнавання днів плідності й заохочувати до здорового способу життя; формувати громадську свідомість, що дитина потребує охорони й піклування як до, так і після народження; пропагувати знання про постабортний синдром серед широкої громадськості.

Необхідно вишколити нову генерацію публічних службовців, які непохитно стоятимуть на засадах біоетики.

Священнослужителям рекомендувати в проповідях і повчаннях приділити особливу увагу проблематиці захисту людського життя, починаючи від моменту запліднення, його цінності й гідності; організувати при парафіях курси на теми біоетики для мирян; поширити практику духовного усиновлення.

Громадським організаціям («Рух за життя», «Інститут біоетики імені Ярослава Базилевича», «Українська асоціація з біоетики», «Інформаційний центр із біоетики», «Школа біоетики») рекомендувати проводити конференції з питань біоетики; виготовити й розмістити інформаційні стенди, присвячені захисту людського життя від моменту запліднення до природної смерті в навчальних закладах, лікарнях і поліклініках, рекомендувати лікарям, середнім медпрацівникам самостійно, згідно із совістю, на підставі християнської моралі, відмовитись від проведення абортів.

\section{Список використаних джерел:}

1. Клятва Гіппократа. Вікіпедія : вільна енциклопедія. URL: https://uk.wikipedia.org/wiki/Клятва_Гіппократа (дата звернення: 07.08.2020).

2. Dichiarazione di Ginevra (1948). Spinsanti S. (a cura di), Documenti di deontologia e etica medica. Milano : Edizioni Paoline, 1985. 33 p.

3. Półtawska W. Samo życie. Częstochowa : Edycja św. Pawła, 2004. 201 s.

4. Giovanni Paolo II. Lettera Enciclica Veritatis splendor, 6 agosto 1983. Città del Vaticano : Libreria Editrice Vaticana, 1983.96 p.

5. Терешкевич Г.Т. Основи біоетики та біобезпеки : підручник. Тернопіль : ТДМУ, 2018. 400 с.

6. Данілова С.О. Кількість абортів в Україні у 2019 році зросла на 60\%. 19.06.2020. URL: https:/greenpost.ua/ news/kilkist-abortiv-v-ukrayini-u-2019-rotsi-zrosla-na-60-i9193 (дата звернення: 07.07.2020).

7. Терешкевич Г.Т. Основи біоетики та біобезпеки : підручник. Тернопіль: ТДМУ, 2018. 400 с.

8. Судо Ж. Аборт. Семья и биоэтика : матер. междун. Симпозиума, 20-23 мая 1998 года. Санкт-Петербург : Изд-во Март. 1998. С. 79-92.

9. Морально-этические проблемы искусственного аборта. Введение в биоэтику : учебное пособие / под. ред. Б.Г. Юдина. Москва : Прогресс-Традиция, 1998. С. 34-39.

10. Терешкевич Г.Т. Основи біоетики та біобезпеки : підручник. Тернопіль : ТДМУ, 2018. 400 с.

11. Українська Радянська Енциклопедія : У 17 т. Київ, 1959. Т. 1. Київ : Головна редакція УРЕ, 1959. 639 с.

12. Терешкевич Г.Т. Основи біоетики та біобезпеки : підручник. Тернопіль : ТДМУ, 2018. 400 с.

13. Clowes B. The Facts of Life: An Authoritative Guide to Life and Family Issues. Virginia : Human Life International, 2001. 448 p.

14. Морально-этические проблемы искусственного аборта. Введение в биоэтику : учеб. пособие / под. ред. Б.Г. Юдина. Москва: Прогресс-Традиция, 1998. С. 34-39. 
15. Терешкевич Г.Т. Основи біоетики та біобезпеки : підручник. Тернопіль : ТДМУ, 2018. 400 с.

16. Цивільний Кодекс України : Закон України від 16 січня 2003 р. № 435-IV / Верховна Рада України. Відомості Верховної Ради України. 2003. № 40-44. Ст. 356.

17. Основи законодавства України про охорону здоров'я : Закон України від 19 листопада 1992 р. № 2802-XII / Верховна Рада України. Відомості Верховної Ради України. 1993. № 4. Ст. 19.

18. Giovanni Paolo II. Lettera Enciclica Veritatis splendor, 6 agosto 1983. Città del Vaticano: Libreria Editrice Vaticana, 1983. $96 \mathrm{p}$.

19. Конституція України : офіційний текст. Київ : КМ, 2013. 96 с.

20. Цивільний Кодекс України : Закон України від 16 січня 2003 р. № 435-IV / Верховна Рада України. Відомості Верховної Ради. 2003. № 40-44. Ст. 356.

21. Назар Н.О. Про необхідність внесення змін в законодавство України у сфері охорони здоров’я як механізм демографічної політики. Демократичне врядування у контексті глобальних викликів та кризових ситуацій : матер. щорічн. наук.-практ. конф. за міжнар. уч., 2-3 квітня 2009 р. Львів : ЛРІДУ НАДУ, 2009.520 с.

22. Кримінальний кодекс України : Закон України від 05 квітня 2001 р. № 2341-III / Верховна Рада України. Відомості Верховної Ради Украӥни. 2001. № 25-26. Ст. 131.

23. Назар Н.О. Про необхідність внесення змін в законодавство України у сфері охорони здоров'я, як механізм демографічної політики. Демократичне врядування у контексті глобальних викликів та кризових ситуацій : матер. щорічн. наук.-практ. конф. за міжнар. уч., 2-3 квітня 2009 р. Львів : ЛРІДУ НАДУ, 2009. 520 с.

24. Комплексний демографічний прогноз України на період до 2050 р. / за ред. Е.М. Лібанової. Київ : Український центр соціальних реформ, 2006. 138 с.

25. Маркевич А.А. Життя людини - найбільша таємниця Творця. Колегія. 1995. № 6. 120 с.

26. Терешкевич Г.Т. Основи біоетики та біобезпеки : підручник. Тернопіль : ТДМУ, 2018. 400 с.

27. Giovanni Paolo II. Lettera Enciclica Evangelium Vitae, 25 marzo 1995. Città del Vaticano : Libreria Editrice Vaticana, 1995. $192 \mathrm{p}$.

28. Хартія працівників охорони здоров’я / Папська Рада до справ душпастирства в охороні здоров'я. Львів :

Медицина і право, 2010. $111 \mathrm{c}$.

29. Терешкевич Г.Т. Основи біоетики та біобезпеки : підручник. Тернопіль : ТДМУ, 2018. 400 с.

30. Clowes B. The Facts of Life: An Authoritative Guide to Life and Family Issues. Virginia : Human Life International, 2001. 448 p.

31. Pelucchi G. Una vita per la vita. Gianna Beretta Molla. Milano : Edizioni Paoline, 1989. 149 p.

32. Хартія працівників охорони здоров’я / Папська Рада до справ душпастирства в охороні здоров'я. Львів : Медицина і право, 2010. $111 \mathrm{c.}$

33. Терешкевич Г.Т. Основи біоетики та біобезпеки : підручник. Тернопіль: ТДМУ, 2018. 400 с.

34. Ваньє Жан. Розбите тіло. Повернення до єднання / пер. з франц. М.М. Якуб'як. Львів : Свічадо, 1993. 144 c.

35. Вуйчич Нік. Життя без кордонів. Шлях до неймовірно щасливого життя. Київ : Форс, 2018. 354 с.

36. Clowes B. The Facts of Life: An Authoritative Guide to Life and Family Issues. Virginia: Human Life International, 2001. 448 p.

37. Dunn H.P. The Doctor and Christian Marriage. New York : Alba House, 2018. 158 p.

38. Терешкевич Г.Т. Основи біоетики та біобезпеки : підручник. Тернопіль : ТДМУ, 2018. 400 с.

39. Натансон Бернард. Обирай життя / пер. зі словацької М.О. Паніва. Львів : Місіонер, 1999. 22 с.

40. Concilio Vaticano II. Gaudium et Spes: Costituzione Pastorale, 7 dicembre 1965. Citta del Vaticano, 1965.64 p.

41. Терешкевич Г.Т. Основи біоетики та біобезпеки : підручник. Тернопіль : ТДМУ, 2018. 400 с.

42. Хартія працівників охорони здоров’я / Папська Рада до справ душпастирства в охороні здоров’я. Львів : Медицина і право. 2010. 111 с.

43. Резолюція ПАРЄ № 1763 (2010) «Право на заперечення з міркувань совісті при наданні легальної медичної допомоги». 08.10.2010. URL: https://www.irs.in.ua/ua/rezolyuciya-parje-1763-2010-pravo-na-zaperechennya-zmirkuvan-sovisti-pri-nadanni-legalnoji-medichnoji-dopomogi(lfnf (дата звернення: 07.07.2020).

44. Терешкевич Г.Т. Основи біоетики та біобезпеки : підручник. Тернопіль: ТДМУ, 2018. 400 с.

45. Congregazione per Dottrina della Fede. Istruzione Donum Vitae, 22 febbraio 1987. Città del Vaticano: Libreria Editrice Vaticana, 1987. 168 p.

46. Giovanni Paolo II. Lettera Enciclica Evangelium Vitae, 25 marzo 1995. Città del Vaticano : Libreria Editrice Vaticana, 1995. $192 \mathrm{p}$.

47. Терешкевич Г.Т. Основи біоетики та біобезпеки : підручник. Тернопіль: ТДМУ, 2018. 400 с.

48. Ней Ф., Петерс М. Шлях центуріона / пер. з англ. 3.Р. Городенчук. Львів : Свічадо, 2001. 112 с.

49. Фрид Л., Салазар И. Пора выздоровления. Помощь и надежда для тех, кто пытается справиться со стрессом после аборта / пер. с англ. ; под ред. Е.А. Шустовой, О.Б. Корсаковой, А.С. Плачковой. Одесса : Издательство Евангельской пресвитерианской церкви, 1993. 118 с.

50. Тофтул М.Г. Совість (сумління). Сучасний словник з етики. Житомир : Вид-во ЖДУ ім. І. Франка, 2014. 416 с. 
51. Святе Письмо Старого та Нового Заповіту (повний переклад, здійснений за єврейськими, арамійськими та грецькими текстами) / O.I. Хоменко. Львів : Місіонер, 2008. 1460 с.

52. Giovanni Paolo II. Lettera Enciclica Evangelium Vitae, 25 marzo 1995. Città del Vaticano : Libreria Editrice Vaticana, 1995. $192 \mathrm{p}$.

53. Терешкевич Г.Т. Основи біоетики та біобезпеки : підручник. Тернопіль : ТДМУ, 2018. 400 с.

\section{References:}

1. Kliatva Hippokrata [Oath of Hippocrates]. URL: https://uk.wikipedia.org/wiki/Kliatva_Hippokrata (Accessed 07 july 2020), Ukraine.

2. 'Dichiarazione di Ginevra (1948)", Spinsanti S. (a cura di) (1985), Documenti di deontologia e etica medica. Edizioni Paoline, Milano, Italy, P.33

3. Półtawska W. (2004), Samo życie [Life itself], Edycja św. Pawła, Częstochowa, Poland, 201 s.

4. Giovanni Paolo II (1983), Lettera Enciclica Veritatis splendor, 6 agosto 1983, Libreria Editrice Vaticana, Città del Vaticano, Vatican, $96 \mathrm{p}$.

5. Tereshkevych, H. T. (2018), Osnovy bioetyky ta biobezpeky [Fundamentals of bioethics and biosafety], Press TDMU, Ternopil', Ukraine, $400 \mathrm{p}$.

6. Danilova Ye. (2020), Kilkist abortiv v Ukraini u 2019 rotsi zrosla na 60\% [The number of abortions in Ukraine in 2019 increased by 60\%]. 19.06. URL: https://greenpost.ua/news/kilkist-abortiv-v-ukrayini-u-2019-rotsi-zroslana-60-i9193 (Accessed 07 july 2020), Ukraine.

7. Tereshkevych, H. T. (2018), Osnovy bioetyky ta biobezpeky [Fundamentals of bioethics and biosafety], Press TDMU, Ternopil', Ukraine, 400 p.

8. Sudo, Zh. (1998), “Abort”, Semia y byoetyka: mater. mezhdun. Sympozyuma [Family and bioethics: mater. int. Symposium], Press Mart, Sankt-Peterbúrh, Russia, 20-23 may.

9. B. Yudyn (1998), 'Moralno-etycheskye problemy yskusstvennoho aborta", Vvedenye v byoetyku: ucheb. posobye / pod. red. B. H. Yudyna [Moral and ethical problems of artificial abortion / Introduction to bioethics: textbook. manual / under. ed. B.G. Yudin], Press Prohress-Tradytsyia, Moskva, Russia, S. 34-39.

10. Tereshkevych, H. T. (2018), Osnovy bioetyky ta biobezpeky [Fundamentals of bioethics and biosafety], Press TDMU, Ternopil', Ukraine, 400 p.

11. Ukrainska Radianska Entsyklopediia (1959), [Ukrainian Soviet Encyclopedia]. U 17 t. Kyiv, T. 1.

12. Tereshkevych, H. T. (2018), Osnovy bioetyky ta biobezpeky [Fundamentals of bioethics and biosafety], Press TDMU, Ternopil', Ukraine, 400 p.

13. Clowes B. (2001), The Facts of Life: An Authoritative Guide to Life and Family Issues. Human Life International, Virginia, USA, 448 p.

14. B. Yudyn (1998), 'Moralno-etycheskye problemy yskusstvennoho aborta", Vvedenye v byoetyku: ucheb. posobye / pod. red. B. H. Yudyna [Moral and ethical problems of artificial abortion / Introduction to bioethics: textbook. manual / under. ed. B.G. Yudin], Press Prohress-Tradytsyia, Moskva, Russia, S. 34-39.

15. Tereshkevych, H. T. (2018), Osnovy bioetyky ta biobezpeky [Fundamentals of bioethics and biosafety], Press TDMU, Ternopil', Ukraine, 400 p.

16. VRU (2003), “Civil Code of Ukraine”, Lists of the Verkhovna rada of Ukraine, vol. 40-44, Art. 356.

17. VRU (1992), Fundamentals of the legislation of Ukraine on health care: Law of Ukraine of 19.11.1992 № 2802- XII / Information of the Verkhovna Rada of Ukraine, № 4. Art. 19, Ukraine.

18. Giovanni Paolo II (1983), Lettera Enciclica Veritatis splendor, 6 agosto 1983, Libreria Editrice Vaticana, Città del Vaticano, Vatican, $96 \mathrm{p}$.

19. VRU (1996), "Constitution of Ukraine", available at: http://zakon5.rada.gov.ua/laws/show/en/254\%D0\%BA/96$\% \mathrm{D} 0 \% \mathrm{~B} 2 \% \mathrm{D} 1 \% 80$ (Accessed 03 July 2020).

20. VRU (2003), "Civil Code of Ukraine", Lists of the Verkhovna rada of Ukraine, vol. 40-44, Art. 356.

21. Nazar, N.O. (2009), "On the need to amend the legislation of Ukraine in the field of health care as a mechanism of demographic policy", Demokratychne vriaduvannia u konteksti hlobal'nykh vyklykiv ta kryzovykh sytuatsij: mater. schorichn. nauk.-prakt. konf. za mizhnar. uch. [Democratic Governance in the Context of Global Challenges and Crises: Mater. annually scientific-practical Conf. for the international], Press LRIDU NADU, Lviv, Ukraine, 2-3 april.

22. . VRU (2001), "Criminal Code of Ukraine", Lists of the Verkhovna Rada of Ukraine, vol. 25-26. Art. 131.

23. Nazar, N.O. (2009), "On the need to amend the legislation of Ukraine in the field of health care as a mechanism of demographic policy”, Demokratychne vriaduvannia u konteksti hlobal'nykh vyklykiv ta kryzovykh sytuatsij: mater. schorichn. nauk.-prakt. konf. za mizhnar. uch. [Democratic Governance in the Context of Global Challenges and Crises: Mater. annually scientific-practical Conf. for the international], Press LRIDU NADU, Lviv, Ukraine, 2-3 april.

24. Kompleksnyi demohrafichnyi prohnoz Ukrainy na period do 2050 r. (2006), [Comprehensive demographic forecast of Ukraine for the period up to 2050] / za red. E. M. Libanovoi. Kyiv: Ukrainskyi tsentr sotsialnykh reform, Ukraine, $138 \mathrm{~s}$. 
25. Markevych A. (1995), Zhyttia liudyny - naibilsha taiemnytsia Tvortsia [Human life is the greatest mystery of the Creator]. Kolehiia. № 6, Ukraine,120 s.

26. Tereshkevych, H. T. (2018), Osnovy bioetyky ta biobezpeky [Fundamentals of bioethics and biosafety], Press TDMU, Ternopil', Ukraine, 400 p.

27. Giovanni Paolo II. (1995), Lettera Enciclica Evangelium Vitae, 25 marzo 1995. Città del Vaticano : Libreria Editrice Vaticana, Vatican, 192 p.

28. Charter of Healthcare Workers (2010) Pontifical Council for Pastoral Care in Health Care. Press Medicine and Law, Lviv, 111 p. Ukraine.

29. Tereshkevych, H. T. (2018), Osnovy bioetyky ta biobezpeky [Fundamentals of bioethics and biosafety], Press TDMU, Ternopil', Ukraine, 400 p.

30. Clowes B. (2001), The Facts of Life: An Authoritative Guide to Life and Family Issues. Human Life International, Virginia, USA, 448 p.

31. Pelucchi G. (1989), Una vita per la vita. Gianna Beretta Molla. Edizioni Paoline, Milano, Italy, 149 p.

32. Charter of Healthcare Workers (2010) Pontifical Council for Pastoral Care in Health Care. Press Medicine and Law, Lviv, 111 p. Ukraine.

33. Tereshkevych, H. T. (2018), Osnovy bioetyky ta biobezpeky [Fundamentals of bioethics and biosafety], Press TDMU, Ternopil', Ukraine, 400 p.

34. Vanie Zhan (1993), Rozbyte tilo. Povernennia do yednannia [Broken body. Return to unity] / per. z frants. M. Yakubiak, Press Svichado, Lviv, Ukraine, 144s.

35. Vuichych Nik (2018), Zhyttia bez kordoniv. Shliakh do neimovirno shchaslyvoho zhyttia [Life without borders. The path to an incredibly happy life], Press Fors, Kyiv, Ukraine. 354 s.

36. Clowes B. (2001), The Facts of Life: An Authoritative Guide to Life and Family Issues. Press Human Life International,Virginia, USA, $448 \mathrm{p}$.

37. Dunn H. P. (2018), The Doctor and Christian Marriage. Alba House, New York, USA, 158 p.

38. Tereshkevych, H. T. (2018), Osnovy bioetyky ta biobezpeky [Fundamentals of bioethics and biosafety], Press TDMU, Ternopil', Ukraine, 400 p.

39. Natanson Bernard (1999), Obyrai zhyttia [Choose life] / per. z slovatsk. M. Paniva. Press Misioner, Lviv, Ukraine, $22 \mathrm{~s}$.

40. Concilio Vaticano II (1965), Gaudium et Spes: Costituzione Pastorale, 7 dicembre 1965, Citta del Vaticano, Vatican,1965. 64 p.

41. Tereshkevych, H. T. (2018), Osnovy bioetyky ta biobezpeky [Fundamentals of bioethics and biosafety], Press TDMU, Ternopil', Ukraine, 400 p.

42. Charter of Healthcare Workers (2010) Pontifical Council for Pastoral Care in Health Care. Press Medicine and Law, Lviv, 111 p. Ukraine.

43. Rezoliutsiia PARIe № 1763 (2010) "Pravo na zaperechennia z mirkuvan sovisti pry nadanni lehalnoi medychnoi dopomohy" [PACE Resolution 1763 (2010) "The right to conscientious objection in the provision of legal medical care"]. 08.10.2010. URL: https://www.irs.in.ua/ua/rezolyuciya-parje-1763-2010-pravo-na-zaperechennya-z-mirkuvan-sovistipri-nadanni-legalnoji-medichnoji-dopomogi, (Accessed 07 july 2020), Ukraine.

44. Tereshkevych, H. T. (2018), Osnovy bioetyky ta biobezpeky [Fundamentals of bioethics and biosafety], Press TDMU, Ternopil', Ukraine, 400 p.

45. Congregazione rer Dottrina della Fede (1987), Istruzione Donum Vitae, 22 febbraio 1987, Libreria Editrice Vaticana, Città del Vaticano, Vatican, $168 \mathrm{p}$

46. Giovanni Paolo II (1995), Lettera Enciclica Evangelium Vitae, 25 marzo 1995, Libreria Editrice Vaticana, Città del Vaticano, Vatican, 192 p.

47. Tereshkevych, H. T. (2018), Osnovy bioetyky ta biobezpeky [Fundamentals of bioethics and biosafety], Press TDMU, Ternopil', Ukraine, 400 p.

48. Nei F., Peters M. (2001), Shliakh tsenturiona [The path of the centurion] / per. z anhl. Z. Horodenchuk. Press Svichado, Lviv, Ukraine, $112 \mathrm{~s}$.

49. Fryd L., Salazar Y. (1993), Pora vyzdorovlenyia. Pomoshch y nadezhda dlia tekh, kto pytaetsia spravytsia so stressom posle aborta [It's time to get well. Help and hope for those trying to cope with post-abortion stress] / per. s anhl.; pod red. E. Shustovoi, O. Korsakovoi, A. Plachkovoi, Press Yzdatelstvo Evanhelskoi presvyteryanskoi tserkvy, Odessa, Ukraine, $118 \mathrm{~s}$.

50. Toftul M. H. (2014), Sovist (sumlinnia) / Suchasnyi slovnyk z etyky [Conscience / Modern Dictionary of Ethics]. Press ZhDU im. I. Franka, Zhytomyr, Ukraine, 416 s.

51. Khomenko, I. (2008), Sviate Pys'mo Staroho ta Novoho Zapovitu (povnyj pereklad, zdijsnenyj za ievrejs'kymy, aramijs'kymy ta hrets'kymy tekstamy) [Scriptures of the Old and New Testament (full translation made by Jewish, Aramaic and Greek texts)], Misioner, L'viv, Ukraine.

52. Giovanni Paolo II (1995), Lettera Enciclica Evangelium Vitae, 25 marzo 1995. Libreria Editrice Vaticana, Città del Vaticano, Vatican, $192 \mathrm{p}$.

53. Tereshkevych, H. T. (2018), Osnovy bioetyky ta biobezpeky [Fundamentals of bioethics and biosafety], Press TDMU, Ternopil', Ukraine, 400 p. 